\title{
PERBANDINGAN TEKNIK PENGAMBILAN KEPUTUSAN MULTI-KRITERIAANTARA METODE ECKENRODE DENGAN METODE FUZZY ECKENRODE PADA KINERJA AGROINDUSTRI
}

\author{
Rahmat Fadhil $^{*}$, M. Syamsul Maarif*), Tajuddin Bantacut ${ }^{* * *)}$, dan Aji Hermawan**) \\ *) Program Studi Teknik Pertanian, Fakultas Pertanian, Universitas Syiah Kuala \\ Jl. Tgk. Hasan Krueng Kalee No. 3, Kopelma Darussalam, 23111 \\ ${ }^{* *)}$ Sekolah Bisnis, Institut Pertanian Bogor \\ Jl. Raya Pajajaran, Bogor 16151 \\ ***) Departemen Teknologi Industri Pertanian, Fakultas Teknologi Pertanian, Institut Pertanian Bogor \\ Gedung Fateta Lantai 2, Kampus IPB Dramaga, Bogor
}

\begin{abstract}
Multi-criteria decision-making system has evolved with various methods. One method that is still being used today is the Eckenrode method. This study aims to compare the methods used in multi-criteria decision-making i.e. between the Eckenrode method and Fuzzy Eckenrode method on agroindustry performances in a decision-making model. To evaluate the two methods, the assessment data from the ten experts on the performance measurement system of agroindustry were used using Human Resource Scorecard (HRSC) method. The results show that both Eckenrode method and Fuzzy Eckenrode method are able to provide a rank-system of an alternative of the same criteria in a decision-making. However, Fuzzy Eckenrode method shows clearer assessment weighting compared to the regular Eckenrode method; therefore, the system of weighting using the Fuzzy Eckenrode method is more recommended in high-level decision making with a high level of accuracy.
\end{abstract}

Keywords: decision-making, Eckenrode, Fuzzy Eckenrode, multi-criteria, weighting

\begin{abstract}
ABSTRAK
Sistem pengambilan keputusan multi kriteria telah berkembang dengan berbagai metode yang beragam. Salah satu metode yang masih terus dipakai saat ini adalah metode Eckenrode. Penelitian ini bertujuan untuk membandingkan metode pengambilan keputusan multi kriteria dengan pendekatan metode Eckenrode biasa dengan metode Fuzzy Eckenrode pada kinerja agroindustri dalam suatu model pengambilan keputusan. Untuk mengevaluasi kedua metode ini digunakan data penilaian terhadap suatu sistem pengukuran kinerja agroindustri dari para pakar sebanyak sepuluh orang dengan metode Human Resource Scorecard (HRSC). Hasil penelitian menunjukkan bahwa metode Eckenrode dan metode Fuzzy Eckenrode mampu memberikan perangkingan suatu alternatif kriteria yang sama dalam suatu pengambilan keputusan. Namun metode Fuzzy Eckenrode menunjukkan penilaian pembobotan yang lebih jelas dibandingan dengan menggunakan metode Eckenrode biasa, sehingga sistem penilaian pembobotan melalui metode Fuzzy Eckenrode lebih direkomendasikan dalam pengambilan keputusan tingkat tinggi dengan akurasi yang juga tinggi.
\end{abstract}

Kata kunci: Eckenrode, Fuzzy Eckenrode, multi kriteria, pembobotan, pengambilan keputusan

${ }^{1}$ Alamat Korespondensi:

Email: rahmat.fadhil@unsyiah.ac.id

\section{PENDAHULUAN}

Teknik pengambilan keputusan terutama dalam menentukan suatu kebijakan yang akan dipilih atau prioritas dari sejumlah alternatif kebijakan yang dapat dilakukan, senantiasa memerlukan suatu metode tertentu. Dalam menghadapi hal tersebut para pakar mencoba menemukan cara-cara efektif dalam penentuannya, apalagi terkait dengan waktu dan pilihan- pilihan yang terkadang terlalu sulit untuk diputuskan dengan cepat. Pendapat para pakar selalu menjadi bagian dari alternatif yang dapat dipertimbangkan dari solusi-solusi yang ditawarkan. Namun, keberagaman latar belakang para pakar dengan kompetensi dan keilmuwan yang berbeda-beda juga dapat melahirkan keputusan yang beragam pula. Oleh karena itu, berbagai metode telah berkembang untuk merumuskan akumulasi pendapat para pakar ini dalam menyajikan 
suatu alternatif pilihan terbaik dari pilihan-pilihan yang diajukan.

Perkembangan teknik pengambilan keputusan telah mengalami berbagai terobosan yang panjang dengan metode yang beragam. Diantaranya adalah metode Technique for Order Performance by Similarity to Ideal Solution (TOPSIS) (Hwang dan Yoon, 1981; Wang 2011; Behzadiana et al. 2012), Analytic Hierarchy Process (AHP) (Ishizakaa 2012; Aminbakhsh, 2013; Saaty, 2013), Simple Additive Weighting (SAW)(Afshari et al. 2010; Jain dan Raj, 2013; Salehi dan Izadikhah, 2014), Weighted Product Model (WPM) (Wang, 2011; Jain dan Raj, 2013), Analytic Network Process (ANP) (Yang et al. 2008; Saaty, 2013; Aragones-Beltran et al. 2014), Multi Atribut Utility Theory (MAUT) (Velasquez dan Hester, 2013; Claudio et al. 2014), Elimination and Choice Expressing Reality (ELECTRE) (Putra et al. 2015), Preference Ranking Organization Method for Enrichment of Evaluations (PROMETHEE) (Hopfe, 2009; Velasquez dan Hester, 2013), Data Envelopment Analysis (DEA) (Lotfi et al. 2011; Velasquez dan Hester, 2013), Value Analysis (VA) and Value Engineering (VE) (SAVE, 2007; Miles, 2015), Visekriterijumslca Optimizacija I Kompromisno Resenje (VIKOR) (Liu dan Wang, 2011; Mardani et al. 2016; ), Interpretive Structural Modeling (ISM) (Jayalakshmi dan Pramod, 2015; Poduval et al. 2015), Bayesian Analysis (BA) (Andraszewicz et al. 2015; Cho, 1998) dan lainnya. Setiap metode memiliki filosofinya tersendiri dan tidak ada satu lebih benar dari lainnya (Tamiz et al. 1998). Termasuk lama ataupun barunya sebuah metode yang dikemukakan tidak berarti bahwa metode lama kurang baik atau kalah dengan metode yang baru.

Diantara metode pengambilan keputusan multi kriteria yang cukup berkembang adalah metode Eckenrode. Metode Eckenrode awalnya dikenal dengan metode Weighting Multiple Criteria (WMC) yang diperkenalkan pertama sekali oleh seorang ilmuwan bernama Robert T. Eckenrode dari Dunlop and Association, Inc sekitar tahun 1965 di Amerika Serikat (Maarif dan Tanjung 2003; Thompson et al. 2006; Kao, 2010). Metode Eckenrode telah dipakai secara luas sampai saat ini dan termasuk metode yang sederhana serta efisien untuk menyelesaikan permasalahan dalam penentuan bobot kepentingan tertentu dalam suatu keputusan (Rijai 2011; Dadelo et al. 2012; Salam, 2014). Metode analisis pembobotan Eckenrode merupakan salah satu metode pembobotan yang digunakan untuk menentukan derajat kepentingan atau bobot (B) dari setiap Kriteria (K) dan
Subkriteria (SK) yang ditetapkan dalam pengambilan keputusan (Eckenrode, 1965; Maarif dan Tanjung, 2003; Salam 2014). Penentuan bobot ini dinilai sangat penting karena akan memengaruhi nilai total akhir dari setiap pilihan keputusan. Konsep yang digunakan dalam metode pembobotan ini adalah dengan melakukan perubahan urutan menjadi nilai dimana misalnya urutan 1 dengan tingkat (nilai) tertinggi dan urutan 5 dengan tingkat (nilai) terendah.

Perbandingan berbagai metode pengambilan keputusan multi kriteria telah banyak dilakukan oleh peneliti, terutama antara satu metode dengan metode lainnya seperti Cho (1998) yang membandingkan antara metode AHP, BA, MAUT, dan ELECTRE dalam pemilihan mobil. Georgiadis (2013) membandingkan antara metode TOPSIS, SAW dan WPM dalam risetnya tentang penggunaan multi kriteria untuk pengambilan keputusan pemilihan teknologi yang memungkinkan bagi Departemen Pertahanan Amerika Serikat. Secara ringkas dapat dipahami bahwa berbagai kombinasi perbandingan metode telah banyak dilakukan. Namun, perbandingan suatu metode dengan memasukkan sistem penilaian yang berbeda masih sangat jarang, contohnya adalah penilaian dengan sistem logika fuzzy.

Aplikasi logika fuzzy dalam pengambilan keputusan adalah untuk lebih memberikan ruang penilaian keputusan dengan rentang tertentu yang tidak pasti pada suatu angka saja. Pada suatu himpunan fuzzy setiap elemen dapat memiliki dua nilai sekaligus, yaitu nilai benar dan nilai salah secara bersamaan. Besaran nilai kebenaran dan kesalahan setiap elemen tersebut sangat tergantung pada bobot atau derajat keanggotaan yang dimilikinya. Kata fuzzy merupakan kata sifat yang berarti kabur atau samar. Dalam banyak kondisi, data yang ada terkadang tidak memadai untuk permasalahan dalam kehidupan nyata karena penilaian manusia yang termasuk preferensi sering kabur atau kurang jelas dan tidak dapat memperkirakan preferensinya dengan nilai numerik yang tepat.

Fuzzy Logic (Logika Fuzzy) pertama kali diperkenalkan oleh Profesor Lotfi A. Zadeh pada tahun 1965 di University of California. Logika fuzzy merupakan pengembangan dari teori himpunan dimana setiap anggotanya memiliki derajat keanggotaan yang bernilai kontinyu antara 0 sampai 1 . Ini bermakna bahwa suatu himpunan fuzzy dapat mewakili interpretasi tiap nilai berdasarkan pendapat atau keputusan dan probabilitasnya. Penilaian 0 menunjukkan salah dan 
penilaian 1 menunjukkan benar serta masih ada nilainilai yang terletak antara benar dan salah tersebut (Wang, 1997; Kusumadewi dan Purnomo, 2010).

Dalam himpunan fuzzy memiliki dua atribut, yaitu (1) linguistik, penamaan suatu grup yang mewakili suatu keadaan atau kondisi tertentu dengan menggunakan bahasa alami, seperti: dingin, sejuk, normal, hangat; (2) numeris, suatu nilai (angka) yang menunjukkan ukuran dari suatu variabel seperti 10, 30, 50 dan sebagainya.

Fungsi keanggotaan (membership function) adalah kurva yang mendefinisikan bagaimana masingmasing titik dalam ruang input dipetakan ke dalam nilai keanggotaan (derajat keanggotaan antara 0 dan 1). Apabila $U$ menyatakan himpunan universal dan $A$ adalah himpunan fungsi fuzzy dalam U maka A dapat dinyatakan sebagai pasangan terurut sebagai berikut (Wang, 1997): $\left.A=\left\{x, \mu_{A}(x)\right) \mid x \in U\right\} \quad$ dengan $\mu_{A}(x)$ adalah fungsi keanggotaan yang memberikan nilai derajat keanggotaan $\mathrm{x}$ terhadap himpunan fuzzy $\mathrm{A}$, yaitu $\mu_{\mathrm{A}}: U \rightarrow[0,4]$.

Dalam himpunan fuzzy terdapat beberapa fungsi keanggotaan himpunan fuzzy baru yang dihasilkan dari operasi dasar himpunan fuzzy, yaitu Intersection $\left(\mathrm{A} \cap \mathrm{B}=\min \left(\mu_{\mathrm{A}}[\mathrm{x}], \mu_{\mathrm{B}}[\mathrm{y}]\right)\right) ;$ Union $\left(\mathrm{A} \cap \mathrm{B}=\max \left(\mu_{\mathrm{A}}[\mathrm{x}]\right.\right.$, $\left.\left.\mu_{\mathrm{B}}[\mathrm{y}]\right)\right)$; Complement $\left(\sim \mathrm{A}=1-\mu_{\mathrm{A}}[\mathrm{x}]\right)$.

Fungsi keanggotaan dinyatakan dengan:

$$
\mu(x)=\left\{\begin{array}{cl}
0 ; & x \leq a \text { atau } x \geq c \\
(b-a) /(x-a) ; & a \leq x \leq b \\
(b-x) /(c-b) ; & b \leq x \leq c
\end{array}\right.
$$

Dalam sistem fuzzy terdapat variabel linguistik, yaitu sebuah variabel yang memiliki nilai berupa katakata dalam bahasa alamiah. Setiap variabel linguistik berkaitan dengan sebuah fungsi keanggotaan tertentu. Sebagai contoh fungsi keanggotaan dalam sistem fuzzy di ilustrasikan dalam Gambar 1.

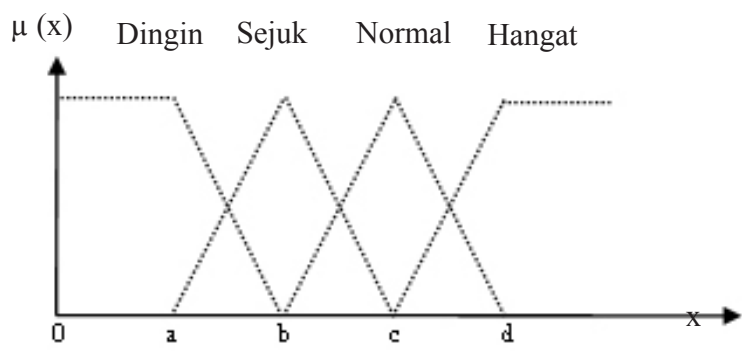

Gambar 1. Fungsi keanggotaan
Penelitian terhadap aktifitas dan kinerja agroindustri memang telah banyak dilakukan, namun kajian yang dilakukan umumnya terbatas pada metode pengambilan keputusan berdasarkan satu pendekatan saja, misalnya metode Eckenrode (Salam 2014), metode AHP (Fahrizal et al. 2014), metode ISM (Jaya et al. 2013), metode Balanced Scorecard (BSC) (Ratnamurni 2011), metode SAW (Maulany 2013), metode Generalized Structured Component Analysis (GSCA) (Santoso et al. 2015) dan lain sebagainya. Sangat jarang penelitian yang melakukan perbandingan antara berbagai metode ataupun berbagai model penilaian dalam satu metode, seperti metode Eckenrode dan metode Fuzzy Eckenrode yang dilakukan dalam penelitian ini. Oleh karena itu, penelitian ini sangat bermanfaat untuk mengetahui dan menerapkan beberapa alat analisis teknik pengambilan keputusan multi-kriteria pada kinerja agroindustri.

Penelitian ini bertujuan membandingkan metode pengambilan keputusan multi kriteria dengan pendekatan metode Eckenrode sebagaimana yang telah dikembangkan dari awal oleh penemunya dengan metode Fuzzy Eckenrode yang merupakan sistem penilaian samar dalam suatu model pengambilan keputusan. Metode Eckenrode dengan sistem penilaian secara pasti dengan suatu angka nominal tertentu yang diberikan oleh para pakar, sedangkan metode Fuzzy Eckenrode adalah penilaian dengan rentang angka tertentu. Penelitian ini terbatas hanya pada ruang lingkup perbandingan antara kedua metode tersebut dengan mengambil suatu kasus pengukuran kinerja agroindustri.

\section{METODE PENELITIAN}

Langkah-langkah yang dilakukan dalam Metode Eckenrode adalah dengan meminta pendapat pakar untuk melakukan perankingan (misalnya ranking dari $\mathrm{R} 1$ sampai dengan $\mathrm{Rn}$, dimana $\mathrm{n}$ ranking, $\mathrm{j}=1,2,3$, ...., $n$; ranking ke $\mathrm{j}=\mathrm{Rj}$ ) untuk setiap kriteria (kriteria ke $\mathrm{i}$, dinotasikan dengan $\mathrm{Ki}$, yang terdapat sebanyak n kriteria, $\mathrm{i}=1,2,3, \ldots ., \mathrm{n}$ ) (Salam 2014) sehingga diperoleh data seperti pada Tabel 1. Kemudian berdasarkan Pij dan Rn-j, dilakukan penghitungan Ni:

$$
\begin{aligned}
& \mathrm{Ni}=\Gamma_{j}=1 \mathrm{P}_{\mathrm{rij}} \times \mathrm{R}_{\mathrm{n}-\mathrm{j}}, \mathrm{j}=1,2,3, \ldots \ldots, \mathrm{n} \\
& \text { Total Nilai }=\Gamma_{\mathrm{i}}=1 \mathrm{~N}_{\mathrm{i}}, \mathrm{i}=1,2,3, \ldots \ldots, \mathrm{n}
\end{aligned}
$$


Tabel 1. Perhitungan Bobot Kriteria Metode Eckenrode

\begin{tabular}{ccccccccc}
\hline \multirow{2}{*}{ Kriteria } & \multicolumn{9}{c}{ Ranking } & \multirow{2}{*}{ Nilai } & \multirow{2}{*}{ Bobot } \\
\cline { 2 - 6 } & $\mathrm{R} 1$ & $\mathrm{R} 2$ & $\ldots \ldots$ & $\mathrm{Rj}$ & $\ldots \ldots$ & $\mathrm{Rn}$ & & \\
\hline $\mathrm{K} 1$ & $\mathrm{P} 11$ & $\mathrm{P} 12$ & $\ldots \ldots$ & & & $\mathrm{P} 1 \mathrm{n}$ & $\mathrm{N} 1$ & $\mathrm{~B} 1$ \\
$\mathrm{~K} 2$ & $\mathrm{P} 21$ & $\mathrm{P} 22$ & $\ldots \ldots$ & & & $\mathrm{P} 2 \mathrm{n}$ & $\mathrm{N} 2$ & $\mathrm{~B} 2$ \\
$\ldots \ldots$ & $\ldots \ldots$ & $\ldots \ldots$ & $\ldots \ldots$ & & & $\ldots \ldots$ & $\ldots \ldots$ & $\ldots \ldots$ \\
$\mathrm{Ki}$ & & & & $\mathrm{Pij}$ & & & & \\
$\ldots \ldots$ & & & & & & & \\
$\mathrm{Kn}$ & $\mathrm{Pn} 1$ & $\mathrm{Pn} 2$ & $\ldots \ldots$ & & & $\mathrm{Pmn}$ & $\mathrm{Nn}$ & $\mathrm{Bn}$ \\
\hline Faktor Pengali & $\mathrm{Rn}-1$ & $\mathrm{Rn}-2$ & $\ldots \ldots$ & $\mathrm{Rn}-\mathrm{j}$ & & $\mathrm{Rn}-\mathrm{n}$ & Total Nilai & 1,00 \\
\hline
\end{tabular}

Keterangan:

Rj : Urutan ranking ke $\mathrm{j}, \mathrm{j}=1,2,3, \ldots \ldots, \mathrm{n}$

$\mathrm{Ki} \quad$ : Jenis kriteria ke $\mathrm{i}, \mathrm{i}=1,2,3, \ldots \ldots, \mathrm{n}$

Pij : Jumlah responden yang memilih ranking ke j, untuk kriteria ke i

$\mathrm{Rn}-\mathrm{j} \quad$ : Faktor pengali ke j, yang diperoleh dari pengurangan banyaknya kriteria atau banyaknya rangking (yaitu $\mathrm{n}$ ) dengan urutan rangking pada kolom tersebut. Misal ada 5 kriteria maka faktor pengali pada kolom rangking ke $3($ misal $j=3$ ) adalah $n-j=5-3=2$

$\mathrm{Bi}$

Bobot kriteria ke i

Selanjutnya, dilakukan penghitungan bobot kriteria Bi, yaitu B1, B2, B3,....., Bn dengan $i=1,2,3, \ldots ., n$, dengan menggunakan rumus: $\mathrm{Bi}=(\mathrm{Ni} /$ Total Nilai $)$.

Untuk mengetahui tingkat kepentingan pada masingmasing subkriteria dalam suatu kriteria, responden juga diminta untuk meranking setiap subkriteria dalam suatu kriteria. Kemudian dengan prosedur yang sama dihitung juga bobot masing-masing subkriteria dalam suatu kriteria (Bli, bobot Subkriteria 1 dalam kriteria i). Dengan demikian, diperoleh Bobot Tertimbang (BT) dari subkriteria 1 dalam Kriteria $\mathrm{i}$, yaitu $\mathrm{BTl}=\mathrm{Bli} \mathrm{x}$ Bi. Selanjutnya, untuk mengetahui nilai pada masingmasing kriteria, responden diminta untuk menilai dari masing-masing subkriteria pada masing-masing kriteria.

Penilaian masing-masing subkriteria dihitung dengan menggunakan rumus rata-rata geometrik dari hasil penilaian dari seluruh narasumber dikalikan dengan BT dari masing-masing subkriteria tersebut. Sehingga pada masing-masing kriteria (K1 sampai K5) dihitung dengan menjumlahkan hasil dari seluruh nilai dari subkriteria-subkriteria yang terdapat pada setiap kriteria. Untuk memberikan penilaian pembobotan oleh para pakar dengan penilaian metode Eckenrode dan Fuzzy Eckenrode dengan preferensi nilai seperti Tabel 2 dan Tabel 3.

\section{Aplikasi Pada Sistem Pengukuran Kinerja Agroindustri}

Untuk mengaplikasikan perbandingan pembobotan menggunakan metode Eckenrode dan Fuzzy Eckenrode, peneliti menggunakan data penilaian terhadap suatu sistem pengkuran kinerja agroindustri mengikuti metode Human Resource Scorecard (HRSC). Metode HRSC ini dikembangkan oleh Brian E. Becker dan Dave Ulrich (2001) dari Harvard Business School yang meliputi: a) pendefinisian human resource competency (HRC). Kompetensi yang dimaksud adalah merupakan pengetahuan, keterampilan, kemampuan dan karakteristik kepribadian yang memengaruhi secara langsung terhadap kinerja; b) pengukuran high performance work system (HPWS). Berfokus pada bagaimana organisasi bekerja melalui setiap fungsi sumber daya manusia (SDM) mulai tingkat makro dan menekankan pada orientasi kerja pada setiap aktivitas; c) pengukuran human resource system alignment (HRSA). Menilai sejauh mana sistem SDM memenuhi kebutuhan implementasi strategi perusahaan (external alignment) dan bagaimana setiap elemen dapat bekerja secara bersama-sama dan tidak mengalami konflik di antara mereka (internal alignment). d) pengukuran human resource efficiency (HRE). Merupakan refleksi bagaimana fungsi SDM dapat membantu perusahaan untuk mencapai kompetensi yang dibutuhkan dengan biaya yang efektif dan efisien. Namun, tidak mengorbankan hasil yang diinginkan. 
Pengukuran efisiensi inti (core efficiency measures). Merepresentasikan pengeluaran SDM yang signifikan dan tidak memiliki kontribusi langsung dengan implementasi strategi perusahaan. Pengukuran efisiensi strategis (strategic efficiency measure). Penilaian efisiensi dari aktivitas SDM dan proses yang dirancang untuk menghasilkan kontribusi SDM; e) pengukuran human resource deliverable (HRD). Mengidentifikasi hubungan sebab akibat (causalitas) yang unik, dimana sistem SDM menciptakan nilai dalam perusahaan.

Para pakar yang diminta pendapat dalam penelitian ini adalah yang dianggap memiliki latar belakang atau kompetensi berkaitan dengan kinerja SDM. Sebanyak 10 orang pakar dipilih untuk memberikan peniliaian dalam dua model sistem pengambilan keputusan multi kriteria, yaitu Eckenrode dan Fuzzy Eckenrode. Referensi penilaian menggunakan skala seperti yang ditunjukkan pada Tabel 2 dan Tabel 3.

\section{HASIL}

Untuk melakukan evaluasi perbandingan sistem pengambilan keputusan multi kriteria dengan pendekatan Eckonrode dan Fuzzy Eckenrode, para pakar diminta untuk memberikan penilaian bobot kepentingan dari sistem pengukuran kinerja suatu agroindustri. Penilaian bobot dalam sistem pengukuran kinerja agroindustri mengikuti metode HRSC, yaitu human resource competency (HRC), high performance work system (HPWS), human resource system alignment (HRSA), human resource efficiency-core efficiency measures (HRE-CEM), human resource efficiency-strategic efficiency measure (HRE-SEM), human resource deliverable (HRD). Gabungan penilaian masing-masing pakar dirangkumkan menjadi satu berdasarkan nilai modus (angka yang paling sering muncul dari populasi atau sampel), sehingga menghasilkan penilaian seperti pada Tabel 4 .

Berdasarkan data penilaian pakar terhadap kriteria penentuan bobot kepentingan, maka dapat dijabarkan kedalam nilai batas bawah (low), tengah (medium) dan batas atas (upper) sesuai dengan fungsi keanggotaan Triangular Fuzzy Number (TFN) seperti terangkum pada Tabel 5.

Pada Tabel 4 terlihat bahwa metode Eckenrode dengan kriteria HRSA dan HRD memiliki nilai dan bobot yang sama, sehingga bila dirangkingkan akan menyulitkan karena tidak adanya perbedaan. Hal ini sungguh berbeda dengan metode Fuzzy Eckenrode pada Tabel 5 yang menunjukkan perbedaan secara jelas antara satu nilai dan bobot dengan yang lainnya. Nilai dan bobot yang berbeda akan semakin memudahkan dalam mengurutkan berdasarkan perioritasnya masingmasing. Untuk melihat perbedaan antara masingmasing alternatif kriteria dapat dilihat pada Gambar 2.

Dalam membuat diagram dengan metode Fuzzy Eckenrode terlebih dahulu data bobot penilaian dilakukan normalisasi sehingga membentuk nilai TFN, sehingga menghasilkan diagram seperti pada Gambar 3.

Tabel 2. Skala perbandingan pembobotan antar kriteria metode eckenrode

\begin{tabular}{clc}
\hline Skala & \multicolumn{1}{c}{ Keterangan } & Nilai \\
\hline 1 & Sangat Tidak Penting & 1 \\
2 & Kurang Penting & 2 \\
3 & Netral & 3 \\
4 & Penting & 4 \\
5 & Sangat Penting & 5 \\
\hline
\end{tabular}

Tabel 3. Skala perbandingan pembobotan antar kriteria metode fuzzy eckenrode dengan Triangular Fuzzy Number (TFN)

\begin{tabular}{clc}
\hline Skala & \multicolumn{1}{c}{ Keterangan } & Fungsi Keanggotaan TFN \\
\hline$\sim 1$ & Sangat Tidak Penting & $1,1,2$ \\
$\sim 2$ & Kurang Penting & $1,2,3$ \\
$\sim 3$ & Netral & $2,3,4$ \\
$\sim 4$ & Penting & $3,4,5$, \\
$\sim 5$ & Sangat Penting & $4,5,5$ \\
\hline
\end{tabular}

Tabel 4. Penilaian pembobotan pakar dengan metode eckenrode

\begin{tabular}{lccccccc}
\hline \multirow{2}{*}{ Kriteria } & \multicolumn{9}{c}{ Urutan } & \multirow{2}{*}{ Nilai } & Bobot \\
\cline { 2 - 7 } & 1 & 2 & 3 & 4 & 5 & & 0,153 \\
\hline HRC & 3 & 2 & 2 & 1 & 2 & 23 & 0,193 \\
HPWS & 5 & 2 & 1 & 1 & 1 & 29 & 0,193 \\
HRSA & 4 & 1 & 3 & 1 & 1 & 26 & 0,173 \\
HRE-CEM & 3 & 2 & 2 & 2 & 1 & 24 & 0,160 \\
HRE-SEM & 2 & 2 & 3 & 2 & 1 & 22 & 0,147 \\
HRD & 4 & 2 & 1 & 2 & 1 & 26 & 0,173 \\
$\begin{array}{l}\text { Nilai } \text { Гkriteria- } \\
\text { urutan) }\end{array}$ & 4 & 3 & 2 & 1 & 0 & 150 & 1 \\
\hline
\end{tabular}


Tabel 5. Penilaian pembobotan pakar dengan metode fuzzy eckenrode

\begin{tabular}{|c|c|c|c|c|c|c|c|c|c|c|c|c|c|c|c|c|c|}
\hline \multirow{3}{*}{ Kriteria } & \multicolumn{15}{|c|}{ Urutan } & \multirow{3}{*}{ Nilai } & \multirow{3}{*}{ Bobo } \\
\hline & \multicolumn{3}{|c|}{1} & \multicolumn{3}{|c|}{2} & \multicolumn{3}{|c|}{3} & \multicolumn{3}{|c|}{4} & \multicolumn{3}{|c|}{5} & & \\
\hline & 1 & $\mathrm{~m}$ & $\mathrm{u}$ & 1 & $\mathrm{~m}$ & $\mathrm{u}$ & 1 & $\mathrm{~m}$ & $\mathrm{u}$ & 1 & $\mathrm{~m}$ & $\mathrm{u}$ & 1 & $\mathrm{~m}$ & $\mathrm{u}$ & & \\
\hline HRC & 2 & 3 & 4 & 1 & 2 & 3 & 1 & 2 & 3 & 1 & 1 & 2 & 1 & 2 & 3 & 70 & 0,154 \\
\hline HPWS & 4 & 5 & 5 & 1 & 2 & 3 & 1 & 1 & 2 & 1 & 1 & 2 & 1 & 1 & 2 & 86 & 0,189 \\
\hline HRSA & 3 & 4 & 5 & 1 & 1 & 2 & 2 & 3 & 4 & 1 & 1 & 2 & 1 & 1 & 2 & 82 & 0,180 \\
\hline HRE-CEM & 2 & 3 & 4 & 1 & 2 & 3 & 1 & 2 & 3 & 1 & 2 & 3 & 1 & 1 & 2 & 72 & 0,158 \\
\hline HRE-SEM & 1 & 2 & 3 & 1 & 2 & 3 & 2 & 3 & 4 & 1 & 2 & 3 & 1 & 1 & 2 & 66 & 0,145 \\
\hline HRD & 3 & 4 & 5 & 1 & 2 & 3 & 1 & 1 & 2 & 1 & 2 & 3 & 1 & 1 & 2 & 80 & 0,175 \\
\hline $\begin{array}{l}\text { Nilai (Гkriteria- } \\
\text { urutan) }\end{array}$ & & 4 & & & 3 & & & 2 & & & 1 & & & 0 & & 456 & 1 \\
\hline
\end{tabular}

Keterangan: $\mathrm{l}=$ low, $\mathrm{m}=$ medium, $\mathrm{u}=$ upper

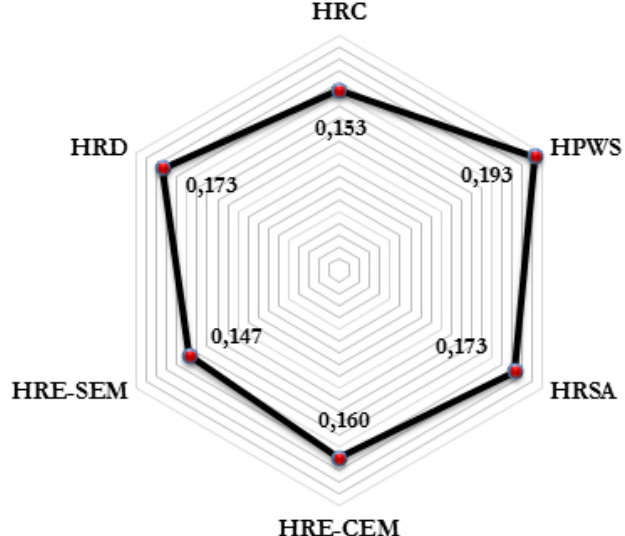

HRE-CEM

Gambar 2. Diagram bobot kriteria dengan metode eckenrode

Metode Eckenrode pada tahap perangkingan terlihat bahwa urutan pertama adalah HPWS sedangkan urutan kedua terdapat dua kriteria terpilih, yaitu HRSA dan HRD, urutan berikutnya secara berturut-turut adalah HRE-CEM, HRC dan HRE-SEM (Gambar 4). Dengan metode Eckenrode biasa menunjukkan perangkingan yang sama pada urutan kedua, sehingga dalam pengambilan keputusan sedikit menyulitkan untuk memutuskan mana yang lebih diutamakan antara satu dengan yang lainnya. Hal ini terlihat berbeda dengan jelas pada metode Fuzzy Eckenrode, dimana secara umum perangkingannya memang sama dengan metode Eckenrode biasa, namun pada urutan kedua karena menggunakan nilai fuzzy terlihat bahwa bobot antara HRSA dan HRD yang sama pada metode Ecenrode biasa dapat dibedakan dengan metode Fuzzy Eckenrode. Oleh karenanya penilaian pembobotan dengan metode fuzzy Eckenrode memberikan penilaian yang lebih

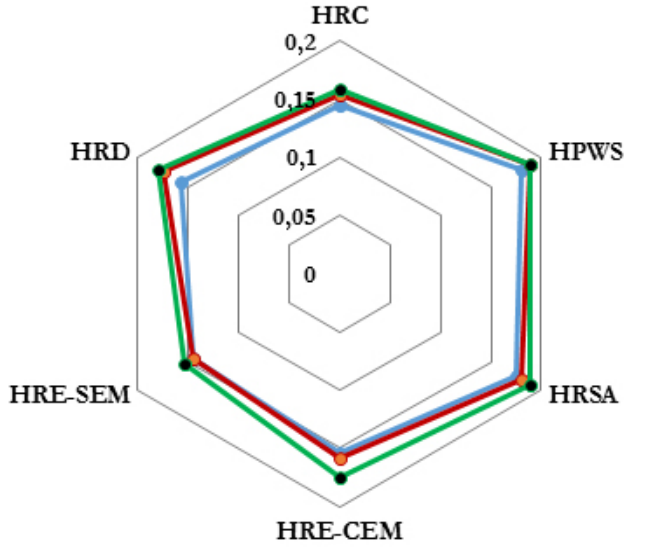

Gambar 3. Diagram bobot kriteria dengan metode fuzzy eckenrode

mudah dalam penentuan suatu kriteria alternatif yang akan diputuskan.

\section{Implikasi Manajerial}

Metode Eckenrode merupakan salah satu metode yang cukup sederhana dan mudah untuk diaplikasikan dalam sistem pengambilan keputusan. Mengembangkan metode Eckenrode menjadi metode fuzzy eckenrode memberikan implikasi keputusan untuk pembobotan suatu kriteria lebih pasti dalam pengambilan keputusan. Perbandingan antara metode Eckenrode dengan metode fuzzy Eckenrode memberikan sebuah ruang dinamika dalam sistem pengambilan keputusan yang terlihat perbedaan secara signifikan. Oleh karenanya dalam sistem pengambilan keputusan tingkat tinggi sangat disarankan penggunaan metode fuzzy Eckenrode lebih diutamakan dibandingkan metode Eckenrode biasa. 


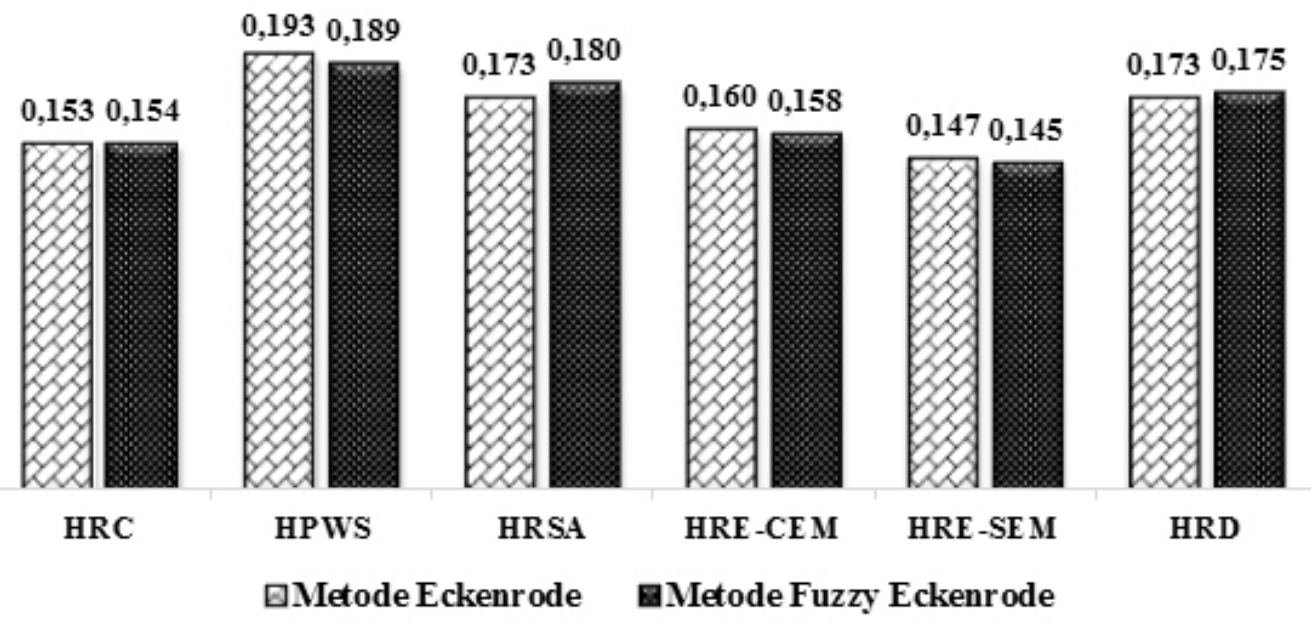

Gambar 4. Perankingan kriteria terpilih

\section{KESIMPULAN DAN SARAN}

\section{Kesimpulan}

Metode Eckenrode dan metode Fuzzy Eckenrode, keduanya mampu memberikan perangkingan suatu alternatif kriteria yang sama dalam suatu pengambilan keputusan. Namun, metode Fuzzy Eckenrode menunjukkan penilaian pembobotan yang lebih jelas dibandingan dengan menggunakan metode Eckenrode biasa. Oleh karena itu, dalam sistem pengambilan keputusan sangat diperlukan kejelasan pembeda antara satu alternatif kriteria dengan alternatif kriteria yang lainnya, sehingga dengan sistem penilaian pembobotan melalui metode Fuzzy Eckenrode lebih direkomendasikan dalam pengambilan keputusan tingkat tinggi yang memerlukan akurasi yang tinggi pula. Hasil penelitian ini juga memberikan implikasi tersendiri bagi para pengambil kebijakan terkait penerapan dalam pengambilan keputusan pada kinerja suatu agroindustri.

\section{Saran}

Penelitian ini telah berhasil menunjukkan perbedaan yang signifikan antara metode pengambilan keputusan Eckenrode dengan fuzzy Eckenrode yang diujicoba pada konteks pengukuran kinerja suatu agroindustri. Masih banyak berbagai metode pengambilan keputusan yang telah berkembang selama ini seperti TOPSIS, AHP, SAW, WPM, ANP, MAUT, ELECTRE, PROMETHEE, DEA, VIKOR, ISM dan lainnya, sehingga perlu juga dilakukan pengujian bagaimana penerapannya bila digunakan dengan pendekatan fuzzy. Sebut saja misalnya perbandingan antara TOPSIS dengan fuzzy
TOPSIS, SAW dengan fuzzy SAW, ELECTRE dengan fuzzy ELECTRE dan lain sebagainya. Termasuk juga aplikasinya dalam penilaian atau pengukuran pada aspek selain kinerja agroindustri.

\section{DAFTAR PUSTAKA}

Afshari A, Mojahed M, Yusuff RM. 2010. Simple additive weighting approach to personnel selection problem. International Journal of Innovation, Management and Technology 1 (5): 511-514.

Aminbakhsh S, Gunduz M, Sonmez R. 2013. Safety risk assessment using analytic hierarchy process (AHP) during planning and budgeting of construction projects. Journal of Safety Research 46: 99-105. https://doi.org/10.1016/j. jsr.2013.05.003.

Andraszewicz S, Scheibehenne B, Rieskamp J, Grasman R, Verhagen J, Wagenmakers E-J. 2015. An Introduction to bayesian hypothesis testing for management research. Journal of Management 41(2): 521-543. https://doi. org/10.1177/0149206314560412.

Aragones-Beltran P, Chaparro-Gonzálezb F, PastorFerrandoc J-P, Pla-Rubioc A. 2014. An AHP (Analytic Hierarchy Process)/ANP (Analytic Network Process)-based multi-criteria decision approach for the selection of solar-thermal power plant investment projects. Energy 66 (1): 222-238. https://doi.org/10.1016/j. energy.2013.12.016.

Becker BE, Ulrich D. 2011. The Human Resource Scorecard: Linking People, Strategy and 
Performance. Boston: Harvard Busininess School Press.

Behzadiana M, Otaghsarab SK, Yazdanib M, Ignatiusc J. 2012. A state-of the-art survey of TOPSIS applications. Expert Systems with Applications 39(17):13051-13069. https://doi.org/10.1016/j. eswa.2012.05.056.

Cho KT. 1998. Multicriteria Decision Methods: An Attempt To Evaluate and Unify. School of Systems Management Engineering, Sungkyunkwan University.

Claudio D, Kremer GEO, Bravo-Llerena W, Freivalds A. 2014. A dynamic multi-attribute utility theory-based decision support system for patient prioritization in the emergency department. IIE Transactions on Healthcare Systems Engineering 4 (1): 1-15. https://doi.org/10.1080/19488300.2 013.879356 .

Dadelo S, Turskis Z, Zavadskas EK, Dadeline R. 2012, Multiple Criteria assessment of elite security personal on the basis of aras and expert methods. Journal of Economic Computation and Economic Cybernetics Studies and Research 46 (4): $65-88$.

Eckenrode RT. 1965. Weighting multiple criteria. Management Science 12(3):180-192. https:// doi.org/10.1287/mnsc.12.3.180.

Fadhil R, Maarif MS, Bantacut T, Hermawan A. 2017. Sistem penunjang keputusan multi kriteria untuk pengembangan agroindustri kopi gayo menggunakan pendekatan fuzzy-eckenrode dan fuzzy-topsis. Jurnal Teknologi Industri Pertanian 27 (1) [dalam proses editing oleh editor/redaksi].

Fahrizal, Marimin, Yani M, Purwanto MYJ, Sumaryanto. 2014. Model penunjang keputusan pengembangan agroindustri gula tebu (studi kasus di Provinsi Nusa Tenggara Timur). Jurnal Teknologi Industri Pertanian 24 (3): 189-200.

Georgiadis D. 2013. Using Multi Criteria Decision Making in Analysis of Alternatives for Selection of Enabling Technology. [Dissertation]. Faculty of the School of Engineering and Applied Science of the George Washington University.

Hopfe CJ. 2009. Uncertainty and Sensitivity Analysis in Building Performance Simulation for Decision Support and Design Optimization, Issue 133, Retrieved Desember 1, 2015, from http:// alexandria.tue.nl/extra2/200911580.pdf.

Hwang CL, Yoon K. 1981. Multiple Attributes Decision Making Methods and Applications. Springer,
Berlin, Heidelberg. https://doi.org/10.1007/9783-642-48318-9.

Ishizakaa A, Pearmana C, Nemeryb P. 2012. AHP Sort: an AHP-based method for sorting problems. International Journal of Production Research 50 (17): 4767-4784. https://doi.org/10.1080/00 207543.2012 .657966 .

Jain V, Raj T. 2013. Evaluation of flexibility in FMS using SAW and WPM. Decision Science Letters 2(4):223-230. https://doi.org/10.5267/j. ds1.2013.06.003.

Jaya R, Machfud, Ismail M. 2013. Aplikasi teknik ISM dan ME-MCDM untuk identifikasi posisi pemangku kepentingan dan alternatif kegiatan untuk perbaikan mutu Kopi Gayo. Jurnal Teknologi Industri Pertanian 21(1): 1-8.

Jayalakshmi B, Pramod VR. 2015. Total interpretive structural modeling (TISM) of the enablers of a flexible control system for industry. Global Journal of Flexible Systems Management 16(1): 63-85.https://doi.org/10.1007/s40171-014$0080-y$.

Kao C. 2010. Weight determination for consistently ranking alternatives in multiple criteria decision analysis. Applied Mathematical Modelling 34(7): 1779-1787. https://doi.org/10.1016/j. apm.2009.09.022.

Kusumadewi S, Purnomo H. 2010. Aplikasi Logika Fuzzy, Untuk Pendukung Keputusan. Edisi Kedua. Yogyakarta: Graha Ilmu.

Liu P, Wang M. 2011. An extended VIKOR method for multiple attribute group decision making based on generalized interval-valued trapezoidal fuzzy numbers. Scientific Research and Essays 6(4):766-776.

Lofti FH, Fallahnejad R, Navidi N. 2011. Ranking efficient units in DEA by using topsis method. Applied Mathematical Sciences 5 (17): 805815.

Maarif MS, Tanjung H. 2003. Teknik-Teknik Kuantitatif untuk Manajemen. Jakarta: PT Gamedia Widiasarana Indonesia.

Mardani A. Zavadskas EK, Govindan K, Senin AA, Jusoh A. 2016. VIKOR technique: a systematic review of the state of the art literature on methodologies and applications. Sustainability 8(1):1-38. https://doi.org/10.3390/su8010037.

Maulany GJ. 2013. Sistem pendukung keputusan untuk menentukan Komoditas unggulan pada daerah pengembangan agroindustri menggunakan metode Simple Additive Weighting (SAW). 
Jurnal Ilmiah Mustek Anim Ha 2(2): 147-155.

Miles LD. 2015. Techniques of Value Analysis and Engineering. 3rd Edition. Portland: Lawrence D. Miles Value Foundation.

Poduval PS, Pramod VR, Jagathy-Raj VP. 2015. Interpretive Structural Modeling (ISM) and its application in analyzing factors inhibiting implementation of Total Productive Maintenance (TPM). International Journal of Quality \& Reliability Management 32(3): 308-331. https:// doi.org/10.1108/IJQRM-06-2013-0090.

Putra AA, Andreswari D, Susilo B. 2015. Sistem pendukung keputusan untuk penerima bantuan pinjaman samisake dengan metode electre (studi kasus: LKM Kelurahan Lingkar Timur Kota Bengkulu). Jurnal Rekursif 3(1):1-11.

Ratnamurni ED. 2011. Kinerja usaha kecil agroindustri makanan dan minuman di Jawa Barat. Portofolio 8 (2): 21-39.

Rijai L. 2011. Penentuan kriteria ilmiah potensi tumbuhan obat unggulan. Journal of Tropical Pharmacy and Chemistry 1 (2): 128-136. https:// doi.org/10.25026/jtpc.v1i2.20.

Saaty TL. 2013. The modern science of multicriteria decision making and its practical applications: The AHP/ANP approach. Operations Research 61(5): 1101-1118. https://doi.org/10.1287/ opre.2013.1197.

Salam AR. 2014. Analisis Penentuan Pelabuhan Impor Produk Hortikultura: Aplikasi Metode Eckenrode. Buletin Ilmiah Litbang Perdagangan 8(1): 1-24.
Salehi A, Izadikhah M. 2014. A novel method to extend SAW for decision-making problems with interval data. Decision Science Letters 3(2): 225-236. https://doi.org/10.5267/j.ds1.2013.11.001.

Santoso I, Yuwandini D, Mustaniroh SA. 2015. Pengaruh kredit dan sumber daya manusia terhadap kinerja UMKM agroindustri dengan pemasaran sebagai variabel antara. Jurnal Manajemen \& Agribisnis, 12(3): 174-182. https://doi.org/10.17358/JMA.12.3.174.

Society of American Value Engineers [SAVE]. 2007. Value Standard and Body of Knowledge. http:// www.valueeng.org/pdf_docs/monographs/ vmstd.pdf. [ 9 june 2016].

Tamiz M, Jones D, Romero C. 1998. Goal programming for decision making: an overview of the current state-of-the-art. European Journal of Operational Research 111: 569-581. https://doi.org/10.1016/ S0377-2217(97)00317-2.

Thompson RL, Iacovou CL, Shirland LE. 2006. A comparison of evaluation techniques for decision analysis involving large attribute sets. Journal of Applied Business Research 22(2): 25-38.

Wang L. 1997. A course in Fuzzy System Control. Prentice-Hall International, Inc., New Jersey.

Wang RT. 2011. performance evaluation method technique for order preference by similarity to ideal solution (TOPSIS). http://researcher.nsc. gov.tw/public/ caroljoe/Data/02182133671.ppt [7 November 2015].

Yang YP, Shieh HM, Leu JD, Tzeng GH. 2008. A novel hybrid MCDM model combined with DEMATEL and ANP with applications. International Journal of Operations Research 5(3):160-168. 